\title{
Are there negative consequences of workforce diversity? \\ Investigating the effect of group faultlines on turnover and organizational performance
}

\author{
Gerhard Krug \\ Institute for Employment Research (IAB), Germany, gerhard.krug@iab.de \\ University of Erlangen-Nuremberg (FAU), gerhard.krug@fau.de \\ Jens Stegmaier \\ Institute for Employment Research (IAB), Germany, jens.stegmaier@iab.de
}

Antje Buche

Studienzentrums der EKD für Genderfragen, antje.buche@sfq.ekd.de

\begin{abstract}
There is strong empirical evidence that workforce diversity is beneficial for organizations. The theoretical concept of faultlines stresses, however, that diversity can also have negative consequences. This is the case when the sub-groups differ not just with regard to one characteristic but with regard to several characteristics simultaneously. This paper is the first to examine the negative consequences of faultlines with large-scale data on organizations in the public and private sector. Fixed-effects regressions are used to investigate the impact of functional (working time, tenure, qualification) and demographic (age, gender, nationality) faultlines on turnover and organizational performance. We also consider the interaction between firm size and faultlines. Regarding turnover, we do not find the expected negative effects of demographic and only limited evidence for functional faultlines. The effects of demographic faultlines on performance, in turn, are negative for small organizations and become positive for organizations with more than 10 members.
\end{abstract}

\section{Key words}

Diversity, faultlines, turnover, organizational performance 


\section{Introduction: from diversity to faultlines}

A number of developments have contributed to an increasingly diverse workforce in many Western countries. For example, the labor force participation of women and particularly married women has significantly increased (Cipollone, D'Ippoliti 2011, Fernández 2013, Blau, Kahn 2013), as has labor force participation of older workers (Leonesio et al. 2012). Also, in many countries, migrants have become an increasing part of the national work force. Of course, these developments do not automatically translate into a more diverse workforce within individual firms and organizations, as is evidenced by persistence of workplace gender segregation (Cohen 2013) and concentration of immigrants (Andersson et al. 2014). However, almost no firm is exempt from these developments altogether. The business case for diversity (Robinson, Dechant 1997), even holds that firms might profit from actively increasing and managing the diversity of their workforce. First of all, diversity can have a positive impact on a firm`s performance because it increases e.g. marketplace understanding, creativity and team problem-solving. Diversity management helps to attract and keep the most talented employees, irrespective of gender, age and nationality. Because turnover is higher for women than for men and women`s family responsibilities induce higher absence rates, diversity management helps to reduce costs regarding female employees,. A similar point can be made for minorities in general, because diversity and diversity management improves minorities` sense of being appreciated and improve work morale. However, diversity has also been termed a "doubleedged sword" (Milliken, Martins 1996). On the one hand, a heterogeneous group composition can bring different knowledge and a variety of perspectives into the work process. This constitutes a resource that leads to better work quality and more creativity and also boosts innovation potential. On the other hand, the potential for conflict and communication barriers may also increase (van Knippenberg and Schippers, 2007). 
Some researchers try to solve the puzzle of when diversity leads to positive or negative outcomes by identifying the contextual factors, moderator and mediator variables (e.g. Guillaume et al. 2015). In contrast, Lau und Murnighan (1998) have argued that the negative consequences of diversity are a function of more than one dimension of diversity overlapping, creating so-called faultlines. A faultline is a hypothetical dividing line that splits a group into two or more subgroups (Lau and Murnighan`s (1998: 328). An example of this is when most of the older members in an organization are men and most of the younger workers are women. In this case age and gender diversity overlap and lead to polarisation within the workforce. Set out to explain the conflicting results in the diversity literature, empirical evidence on faultlines seems no less inconsistent than diversity research in general (Knippenberg, Schippers 2007; Choi, Sy 2010).

One potential reason might be that both diversity and faultline research has a strong focus on work groups. Here it has been shown that increasing diversity can be associated with both positive and negative effects. The findings of studies in this field are not very consistent, however, and often depend on the specific operationalisation of diversity and different context factors (see Buche et al., 2013).

Besides work groups, there is a small but growing literature that takes entire organizations as units of analysis. We will distinguish between demographic and functional diversity. Following Williams/O'Reilly (1998) diversity in demographic characteristics like age, sex and ethnicity is more or less readily detectable but rather low in job relatedness whereas functional characteristics like tenure or education are more job-related but obviously less salient especially in larger groups like we use in this study. Starting with evidence on organisational performance, this field of diversity research focusses on demographic characteristics. Here too, the findings remain inconsistent: with regard to age diversity in organisations, both Li et al. (2011) and Ilmakunnas and Ilmakunnas (2011) find positive 
effects on organisational performance, whereas Kunze et al. (2010) find negative effects. Also in the study by Backes-Gellner and Veen (2013) age diversity is found to have a negative effect on performance of organisations with routine tasks, but a positive effect in innovative companies. In contrast, using the same data, Buche et al. (2013) do not find any effect of age diversity on organisational productivity. However, in that study and in Trax et al. (2012) ethnic diversity is found to have a positive impact on productivity. The same results are also obtained in other studies examining the effects of cultural and ethnic diversity on similar outcome variables, such as financial success, market value, sales revenues, market shares or profit (Herring, 2009; Richard, 2000). Herring (2009) also finds gender diversity to have positive effects on sales revenues and profit, whereas Ilmakunnas and Ilmakunnas (2011) find no evidence of effects on productivity. This inconsistency in the results is also confirmed by Boerner et al. (2012) in their meta-analysis about gender diversity and organisational success.

While several studies have estimated the effects of diversity on organisations' productivity, there are considerably fewer studies to date that examine the impact on turnover. Among those, demographic as well as functional characteristics are investigated. In the studies by Alexander et al. (1995) and Pfeffer and O'Reilly (1987) it can be seen that average turnover rates rise with increasing diversity in job tenure. This effect can also be detected for educational diversity, whereas diversity in employment status (part-time vs. full-time) reduces turnover (Alexander et al., 1995). Zatzick et al. (2003) also show that the likelihood of a person leaving an organisation falls if the share of people from their own ethnic group in the organisation grows. Ali et al. (2010), on the other hand, do not find that ethnic diversity has any effect on turnover.

According to both Harrison and Klein (2007) and Dawson (2012), the often very contradictory findings from diversity research are largely the result of the measures of 
diversity used. They therefore call for adequate measures that have a sound theoretical background and should differentiate between positive and negative effects of diversity. Measures that can depict diversity (variation) are relevant if one aims at analysing positive effects. Contrary, if negative consequences are expected, measures should be used that can portray separation or polarisation, in other words the formation of subgroups (Harrison and Klein, 2007).

Another important reason for the broad spectrum of findings obtained in diversity research is that the analyses are each restricted to individual dimensions of diversity, for example age or gender diversity. Although some studies also examine several characteristics simultaneously, there, too, the measures used are one-dimensional, for instance when gender diversity is examined in addition to age diversity. In contrast, Alexander et al. (1995) show that not only the individual dimensions of diversity but also their interplay can be regarded as having an impact on the likelihood of separation. Following Blau (1977), they reach the conclusion that the effects of demographic structures can only be analysed adequately if multidimensionality is taken into account.

This aspect is also emphasised by Lau and Murnighan (1998). They assume that negative consequences of diversity will appear above all when several dimensions of diversity overlap. An example of this is when most of the older members in an organisation are men and most of the younger workers are women. In this case age and gender diversity overlap and reinforce the polarisation within the organisation. For this situation, Lau and Murnighan introduced the metaphor of a "faultline". What they mean by a faultline is a hypothetical dividing line that splits a group into two or more subgroups (Lau und Murnighan, 1998: 328).

By using the faultline concept we take on both of the problems in diversity research that were described above. First, the faultline concept adequately portrays conflicts in the sense 
of separation and second, it takes the multidimensionality of diversity into account. Comparative analyses in which faultline and diversity measures are used simultaneously show that faultlines are generally a better predictor of conflicts and/or performance (for example Bezrukova et al., 2009; Lau and Murnighan, 2005; Li and Hambrick, 2005; Thatcher et al., 2003).

Unlike diversity research, however, analyses of faultline effects have so far been conducted only at the level of work groups. Here, empirical research essentially confirms the negative consequences of faultlines anticipated by Lau and Murnighan (1998). Thatcher and Patel (2011) find in their meta-analysis, for instance, that demographic faultlines are often accompanied by conflicts in the group and reduce group performance. However, the studies published so far on the consequences of faultlines exhibit a number of shortcomings. For example, they frequently do not depict real work situations (laboratory studies) or do not necessarily correspond to natural work groups in organisations due to the composition of their teams (teams of students or artificial restriction to certain team sizes in order to simplify measurement). As the work groups generally come from just one organisation, it is also unclear whether the findings depend on the specific context of one organisation. Furthermore, the evaluation of the work groups' performance is frequently based on assessment by superiors or self-assessment by the team members. Objective indicators are only rarely used to measure performance. The findings of the studies are therefore only applicable to typical work situations and constellations to a limited extent and their measurement is often dependent on the subjective assessment of individuals.

In the present study, the faultline concept is transferred from work groups to organisations, to our knowledge for the first time in an empirical analysis. Hypotheses are derived and tested, including differential effects of faultlines with regard to organisational size. The procedure is as follows: the next section introduces the subject of faultlines in more detail 
and argues why they can show effects not only in small groups such as work teams, but also in large groups such as entire organisations. Hypotheses are derived about the impact on turnover and performance in the organisation. This is followed by a description of the combined employer and employee data that serve as the data basis for the study, as well as a measure developed by Trezzini (2013) for analysing multidimensional demographic diversity. In the following section the results of panel regressions are presented. A discussion rounds off the paper.

\section{Theoretical considerations}

In the field of diversity research a small but substantial area of research already deals with the overall organisational level. This perspective is still missing entirely in research on faultlines. In addition to this, the theoretical mechanisms in work group research generally are social-psychologically motivated: "Diversity matters because individuals give social significance to categories or groups they associate with various people" (DiTomaso et al. 2007:475). Some of these theories emphasise positive effects of diversity and argue that the results of work groups are of higher quality and more innovative the more diverse these work groups are as they can rely on various perspectives and a wealth of knowledge (van Knippenberg, Schippers 2007: 517f). Other theories like the social categorisation perspective or the similarity/attraction perspective point out potential drawbacks of diversity and claim that ,that work groups function more smoothly when they are homogenous than when they are more diverse“ (ebd.: 517f).

However, such argumentation can hardly be applied directly to large groups such as entire organisations. Whereas the members of work groups interact with each other on a daily basis and constantly have to come to agreements amongst themselves, this does not apply 
to the members of larger organisations. Although groups separated by faultlines may also emerge in larger organisations, it must still be taken into account that a large number of workers have no regular contact with each other. In order to approach the social mechanisms at organisational level, we therefore orientate ourselves towards arguments presented by Habyarimana et al. (2007). They argue that mechanisms through which two antagonistic subgroups within a city district can impede the production of public goods. Public goods or also public services (Varian, 1992) can be used by several individuals at the same time and nobody can be excluded from using them. When individuals use this public good, but contribute few resources or none at all to producing it, this is known as a free-rider problem.

Organisations can be seen to produce public goods for their members. For example if in economic organisations a high level of productivity and a good operating result are achieved, this benefits the whole workforce, for example via wage increases and secure jobs, even if not every individual was involved to the same extent in generating them. This is very similar to the public goods problem discussed by Habyarimana et al. (2007) ${ }^{1}$. Also, the company climate, working conditions or specific remuneration rules are also "produced". Therefore, we apply the argumentation of Habyarimana et al. (2007) to organisations by claiming that faultlines could undermine the ability of a workplace community to produce such public goods.

According to Habyarimana et al. (2007), the following mechanisms through which demographic polarisation (or faultlines in our case) can impede the production of public goods can be listed. First, demographic subgroups in the workplace may have different preferences regarding which public goods should be produced. In market organisations, some employees will welcome, for example, flexible working hours, the possibility to

\footnotetext{
${ }^{1}$ Habyarimana et al. (2007) refer to the formation of groups based on ethnic group membership, but the argumentation can easily be applied to groups with multidimensional differences.
} 
work part-time or performance-related wage components; others will prefer fixed working hours or seniority-based wages ("commonalities of tastes"). It can also be of importance that individuals benefit positively from the utility of members of their own group and gain no benefit or even negative benefit from the utility of the members of other groups ("taste for discrimination"). Thus conflicts may arise when it is a matter of fighting for certain working conditions that are only advantageous for one demographic group in an organisation (or also reducing previous disadvantages, for example gender or age discrimination).

In addition to the questions of which public goods should be produced and to whose advantage, the subgroups may differ with regard to how the goods should be produced. Homogeneous groups often have a collective reservoir of values and preconceptions, which facilitates interaction and consensus building. In heterogeneous groups the opposite is the case. Ethnic affiliation and any related language barriers are of particular importance here. However, a different composition with regard to gender or age can also impede the search for consensus with regard to the production of public goods within the workplace. Finally, it is also important with whom individuals interact in the production of public goods. For instance, uncooperative behaviour towards members of an individual's own group can be sanctioned by the other members of the group, while similar behaviour towards members of the other group is tolerated. This, too, may hamper the production of public goods in polarised organisations. From these considerations it is now possible to derive hypotheses for the impact of faultlines in organisations as compared to single work units within organisations.

First, faultlines in organisations, like in work groups, might contribute to an increase in turnover. Strong faultlines could lead to the public goods in the organisation not being produced to the satisfaction of all the members. As is known in the literature (Egan et al., 
2004; Lambert et al., 2001), dissatisfaction with working conditions induces members to leave the organisation.

Hypothesis 1a: Demographic and functional faultlines have a positive impact on turnover.

Because conflicts among diverse workers are easier to avoid in larger units, we also expect faultlines to have a smaller effect, the larger the organisation.

Hypothesis 1b: The positive effect of demographic and functional faultines on turnover decreases with organisation size

Second, the reduced propensity to work together in a cooperative manner as a result of faultlines should lead to efficiency losses. This should have an impact on the performance of the organisation as a whole. Only when all the members contribute in a largely cooperative manner towards fulfilling the organisation's purpose, can an organisation achieve the largest possible production output with the given members. Conversely, it should apply that faultlines impede cooperation, thereby reducing performance.

Hypothesis 2a: Demographic and functional faultines have a negative effect on organisational performance.

Again, we expect effects on organisational performance to vary with size. In this case, we expect smaller organisations to be more adversely impacted by faultlines than larger organisations.

Hypothesis 2b: The negative effect of demographic and functional faultlines on organisational performance decreases with organisation size. 


\section{Data and method}

The empirical analysis is based on linked employer-employee survey data of the Institute for Employment Research (IAB). Employer data is derived from a representative establishment panel survey, the IAB Establishment Panel. The survey has been conducted in western Germany since 1993 and in eastern Germany since 1996. It is carried out as an annual panel survey as of 30 June of each year and gathers information from some 16,000 establishments with one or more employees liable to social security contributions. The survey data is linked to administrative data on all the individuals employed in the surveyed establishments. Our sample comprises the years 2000 to 2008 and contains private as well as administrative organisations, but excludes the non-profit sector. Because for single employee establishments there cannot per definition be a faultline, we excluded those establishments from the analysis.

Our level of analysis is the organisation, where we use the individual data only to construct our faultline indicator for the organisational level. When selecting the demographic characteristics to be considered, we orientate ourselves towards the characteristics that are discussed most frequently in the literature, that is gender, age and migration background. However, the latter has to be approximated by nationality owing to the administrative origin of the data, which is why the actual number of individuals with a migration background is most likely underestimated. For functional diversity we use factors most prominent in the literature, that is working-time, qualification, and organisational tenure.

For testing Hypothesis 1 as a measure of turnover we use the so-called churning rate (CR) (Burgess et al., 1999 as the dependent variable. This measure indicates the rate of stockneutral member flows in an organisation. It has the advantage of holding constant effects 
of organisational growth or contraction processes that are also inducing higher turnover rates. $^{2}$

To test Hypothesis 2 we use a conventional measure of performance in economic organisations, (labour) productivity, as the dependent variable. Productivity is calculated on the basis of the organisation's sales revenues. The sales revenues are first adjusted to take into account intermediate inputs, for example raw materials purchased, external services or rents, and then related to the total number of employees (gross value added per worker) and logarithmised to allow interpretation in terms of percentages. As productivity is not available for banks, insurance companies and the public sector, testing hypothesis 2 is based on a sub-sample of our data. To reflect this, for hypothesis 1 we included a dummy indicator variable in the regression analysis to see whether the two samples differ. This was not the case. We also restricted the results for turnover to the sample used for analysing performance and found no differences.

The key independent variable in the analysis is the manifestation of faultines within an organisation. In order to measure this, we use the polarised multidimensional diversity (PMD) measure proposed by Trezzini (2013), which closely follows the faultline concept developed by Lau and Murnighan (1998). The measure can be seen as a multidimensional generalisation of the measure of income polarisation suggested by Esteban and Ray (1994). In contrast to other ways of measuring faultlines that are also multidimensional, Trezzini's (2013) measure focuses on the emergence of two or more polarised sub-groups. It therefore refers more strongly to the theoretical mechanism of faultlines than other measures (see above).

\footnotetext{
${ }^{2}$ To calculate the churning rate the following formula is used: $\mathrm{H}+\mathrm{S}-\mid \mathrm{H}-\mathrm{S} / / 0,5 *\left(\mathrm{~N}_{\mathrm{t}}+\mathrm{N}_{\mathrm{t}}-1\right)$. Here $\mathrm{H}$ is the number of hires and $\mathrm{S}$ the number of separations in a period and the denominator is the average employment in the same period.
} 
Moreover, PMD has the advantage of being well suited for categorical variables, and many sociodemographic characteristics do not have a cardinal scale level. However, the available variables with a higher scale level (for example age) have to be divided into categories accordingly. Because PMD is neither implemented in stata (our statistical software of choice) nor available ad a user-written ad-on, we had to write our own stata routine. Because the computation was cumbersome, it was not possible to divide the continuous variables into more than two categories. ${ }^{3}$

To analyse demographic faultlines we examine the characteristics of age (dichotomised: 1 if older than 30), gender and nationality (dichotomised: 1 if female and German, respectively). Regarding functional faultlines we use working time (dichotomised: 1 if fulltime), organisational tenure (dichotomised: 1 if two years or less) and qualification (dichotomised: 1 if low-qualified). ${ }^{4}$

PMD is defined as follows:

$$
P M D=\sum_{i=1}^{n} \sum_{j=1}^{n}\left(p_{i}+p_{j}\right) p_{i} p_{j} d_{i j}
$$

where $p_{i}$ and $p_{j}$ stand for the relative frequency with which a specific combination of characteristics $i$ (for example in the context of demographic diversity younger man with German nationality) or $j$ (for example older woman with German nationality) occurs, while $d_{i j}$ is a measure of the diversity between the combinations of characteristics $i$ and $j$. Following the example given above, the combinations of younger man with German nationality and older woman with German nationality differ in two out of three

\footnotetext{
${ }^{3}$ We also tried the routine asw.cluster by Meyer and Glenz (2017), that among others computes PMD. However, the routine is took several days to compute PMD even for one year, presumably because it is optimized for small-group data and not for group sizes of at the extreme more than 200.

${ }^{4}$ We test our hypotheses in separate regressions (one for demographic, one for functional faultlines) but checked also specifications with both measures as independent variables in one model. Our results are robust in all specifications (see Table A2).
} 
characteristics and therefore $d_{i j}=\frac{2}{3}=0.66$. PMD reaches a maximum of 0.5 when the organisational member splits into two groups of equal size with maximum diversity $\left(p_{i}+p_{j}=1 ; p_{i}=p_{j}=0.5 ; d_{i j}=d_{j i}=1\right)$. To facilitate interpretation, we standardise this measure and show it as a percentage between 0 and 100 . The value 0 indicates that all of an organisation's members belong to one socio-demographically homogeneous group. The value 100, on the other hand, is reached if all the members in an organisation are divided into two groups of equal size and with maximum diversity. A value of 70 then means that the faultline in the organisation amounts to $70 \%$ of the maximum possible extent but without permitting conclusions regarding the number of subgroups. We use stata to test compute PMD for each firm in each year of the data.

The panel structure of the data permits panel regressions to be conducted to test the hypotheses. In order to test for unobserved, time-invariant heterogeneity, we use the classic fixed-effects model that utilises deviations from the organisation-specific means for identification. In contrast to the simple OLS model, this makes it possible to control the distorting influence of unobserved, (quasi) time-constant factors, such as corporate culture. As a result of this method, our covariates do not include any time-invariant variables such as economic sector or east-west location. In all of the models we also control for establishment size, workforce structure (share of skilled workers, share of fixed-term contracts, share of part-time employees ${ }^{5}$, share of apprentices) and the organisations' technical equipment. The latter is based on an assessment by the organisations using a scale from 1 (new) to 5 (old). Finally, we take cyclical influences into account using the year dummies for the period concerned.

\footnotetext{
${ }^{5}$ Share of part-time workers is not applied in the case of functional faultlines as the share of part-timer workers is part of the faultline measure.
} 


\section{Results}

Table 1 first provides an overview of the composition of the organisations in the sample. The values of the dependent variables and the value of the measure of faultlines as the key independent variable are of particular interest. Turnover stands at about 6 percent. This means that the average organisation replaces about 6 percent of its members within a period of six months without the size of the establishment changing. The productivity measure stands at 11.33. If the value is delogarithmised, this yields a productivity of approximately 83,000 euros per employee. The faultline measure combining age, gender and nationality is on average 27 percent, in other words in the lower third of the spectrum.

Table 1: Description of the sample

\begin{tabular}{lll}
\hline & Mean & Standard deviation \\
\hline Churning rate & 0.06 & 0.18 \\
Log. gross value added per worker in euros & 11.33 & 0.95 \\
Demographic faultline & 27.29 & 11.79 \\
Functional Faultline & 30.10 & 13.38 \\
No. of employees & 174.12 & 826.29 \\
Skilled workers (share) & 0.69 & 0.27 \\
Part-time workers (share) & 0.21 & 0.25 \\
Fixed-term workers (share) & 0.06 & 0.15 \\
Apprentices (share) & 0.05 & 0.10 \\
Technical equipment (1=good to 5=poor) & 2.21 & 0.76 \\
\hline Basis: sample of model (1) in Table A1. A description of the other models, apart from the logarithmised gross value \\
added per worker, is dispensed with, as the description of the other sample yields very similar results.
\end{tabular}

Table 2: Distribution of demographic faultline-extent in organisations

\begin{tabular}{|c|c|c|c|c|c|c|}
\hline \multirow[b]{2}{*}{ Size of Organisation } & \multicolumn{5}{|c|}{ Percentile } & \multirow[t]{2}{*}{$\begin{array}{l}\text { Standard } \\
\text { deviation }\end{array}$} \\
\hline & $10 \%$ & $25 \%$ & $50 \%$ & $75 \%$ & $90 \%$ & \\
\hline 2-4 members & 0 & 0 & 0 & 33.3 & 39.5 & 20.8 \\
\hline 5-9 members & 0 & 25 & 32 & 35.4 & 41.7 & 13.7 \\
\hline $10-19$ members & 18.4 & 26.4 & 31.8 & 33.9 & 36.5 & 8.8 \\
\hline 20-49 members & 19.3 & 26.2 & 31 & 33.1 & 34.3 & 6.9 \\
\hline 50-99 members & 21.6 & 26.9 & 30.8 & 32.7 & 33.6 & 5.7 \\
\hline 100-199 members & 22.5 & 27.2 & 30.6 & 32.5 & 33.3 & 5.1 \\
\hline 200 and more members & 24.4 & 28 & 30.4 & 32 & 33.0 & 4.2 \\
\hline Overall & 0 & 25 & 30 & 33.2 & 35 & 11.8 \\
\hline
\end{tabular}

Table 2 shows the distribution of the faultline measure for all organisations and separately for each size category. $90 \%$ of all organisations exhibit values between 0 and 35 percent, 
where the lower values of the faultline measure are driven by smaller organisations. The slight accumulation of organisations with a faultline value of zero among smaller organisations is due to organisations in which all the members belong to the same demographic category, which is more likely in smaller organisations.

Table 3: Effects of faultlines on organisational turnover

\begin{tabular}{|c|c|c|c|c|}
\hline Variables & $\begin{array}{l}\text { Model } 1 \\
\text { Demographic } \\
\text { Faultline }\end{array}$ & $\begin{array}{l}\text { Model } 2 \\
\text { Demographic } \\
\text { Faultline }\end{array}$ & $\begin{array}{l}\text { Model } 3 \\
\text { Functional } \\
\text { Faultline } \\
\end{array}$ & $\begin{array}{l}\text { Model } 4 \\
\text { Functional } \\
\text { Faultline } \\
\end{array}$ \\
\hline \multirow[t]{2}{*}{ Faultline measure } & 0.00015 & 0.00011 & $0.00012 *$ & 0.00006 \\
\hline & $(0.000)$ & $(0.000)$ & $(0.000)$ & $(0.000)$ \\
\hline \multirow[t]{2}{*}{ 5-9 members } & 0.00039 & 0.00152 & 0.00159 & -0.00291 \\
\hline & $(0.004)$ & $(0.005)$ & $(0.004)$ & $(0.005)$ \\
\hline \multirow[t]{2}{*}{ 10-19 members } & 0.00582 & -0.00228 & 0.00683 & 0.00854 \\
\hline & $(0.005)$ & $(0.009)$ & $(0.005)$ & $(0.008)$ \\
\hline \multirow[t]{2}{*}{ 20-49 members } & 0.00860 & 0.00563 & 0.00988 & 0.00062 \\
\hline & $(0.007)$ & $(0.013)$ & $(0.007)$ & $(0.013)$ \\
\hline \multirow[t]{2}{*}{ 50-99 members } & $0.02484 * *$ & 0.00750 & $0.02602 * *$ & 0.02818 \\
\hline & $(0.009)$ & $(0.017)$ & $(0.009)$ & $(0.019)$ \\
\hline \multirow[t]{2}{*}{ 100-199 members } & $0.04296 * * *$ & 0.01977 & $0.04420 * * *$ & 0.03940 \\
\hline & $(0.012)$ & $(0.018)$ & $(0.012)$ & $(0.031)$ \\
\hline \multirow[t]{2}{*}{200 and more members } & $0.06562 * * *$ & $0.04688 *$ & $0.06707 * * *$ & 0.02993 \\
\hline & $(0.015)$ & $(0.023)$ & $(0.015)$ & $(0.022)$ \\
\hline \multirow[t]{2}{*}{ 5-9 members*faultline } & & -0.00003 & & 0.00014 \\
\hline & & $(0.000)$ & & $(0.000)$ \\
\hline \multirow[t]{2}{*}{ 10-19 members*faultline } & & 0.00028 & & -0.00005 \\
\hline & & $(0.000)$ & & $(0.000)$ \\
\hline \multirow[t]{2}{*}{ 20-49 members*faultline } & & 0.00010 & & 0.00030 \\
\hline & & $(0.000)$ & & $(0.000)$ \\
\hline \multirow[t]{2}{*}{ 50-99 members*faultline } & & 0.00059 & & -0.00006 \\
\hline & & $(0.001)$ & & $(0.000)$ \\
\hline \multirow[t]{2}{*}{ 100-199 members*faultline } & & 0.00079 & & 0.00016 \\
\hline & & $(0.001)$ & & $(0.001)$ \\
\hline \multirow[t]{2}{*}{200 and more members*faultline } & & 0.00063 & & $0.00120^{*}$ \\
\hline & & $(0.001)$ & & $(0.000)$ \\
\hline
\end{tabular}

Notes: Fixed effects regressions; additional control variables: establishment size, share of skilled workers, share of fixedterm contracts, share of part-time employees, share of apprentices and the organisations' technical equipment; robust standard errors in parentheses; $* * *, * * *$ denotes significance at the $0.1,1$, or 5 percent level, respectively.

The results of the regression analysis are presented in the following. ${ }^{6}$ We first discuss the findings on member turnover, both for demographic and functional faultlines (Table 3). Starting with turnover effects of demographic faultlines, the covariates do not indicate any

\footnotetext{
${ }^{6}$ Full results can be found in Table A1.
} 
special features: the shares of skilled workers and of apprentices are only slightly related to turnover. In contrast, a clear increase in turnover is found with a greater use of part-time staff and - as expected - in particular with fixed-term employment. On the whole these findings refer to explanations from human capital and segmentation theory, according to which the use of staff with higher skill levels should be accompanied by longer employment duration (and therefore with a lower level of turnover on average), whereas non-standard forms of employment (for example fixed-term employment) are associated with a higher level of turnover in the workforce.

In the model without organisation-size interaction, the coefficient of demographic faultlines in an organisation stands at 0.00015. Accordingly, the turnover in an organisation increases by about 0.015 percentage points with every one-percent increase in the demographic faultline. Although the coefficient exhibits the expected sign this effect is, however, statistically insignificant. The same is true in Model 2, where the faultline measure is interacted with organisation size. Because of this the data does not support either hypothesis $1 \mathrm{a}$ or hypothesis $1 \mathrm{~b}$ for demographic faultlines. Turning to functional faultlines, in Model 3 in Table 3 the coefficient on turnover is 0.00012 and significant at the $5 \%$ level. If the functional faultline increases by one percent, turnover increases by about 0.012 percentage points. ${ }^{7}$ In Model 4 we interact the measure of functional faultlines with organisation size. There is no significant difference of the observed effect within classes of organisation size. An exception is the largest class of organisations with 200 and more members, indicating that the overall effect is mainly driven by very large organisations. This means that for functional faultlines, we find support for hypothesis 1a but not for hypothesis $1 b$.

\footnotetext{
${ }^{7}$ To assess the meaning of the magnitude of the coefficient it is helpful to hypothesise a 10 percent increase in faultline which leads to an increase in turnover of 0.12 percentage points. Given the mean turnover rate of 6 percent this effect can be regarded as rather small.
} 
When examining organisational performance (see Table 4), it can be seen for the control variables that a larger share of skilled workers is associated with an increase in value added. Apprentices, as well as part-time and fixed-term employees, on the other hand, reduce the value of the dependent variable. One possible explanation for this is that, due to the relatively shorter payoff period of human capital investment for part-time workers and employees on fixed-term contracts, among other things, these member groups generate lower returns than full-time or permanent staff. In the case of apprentices it must be taken into account that this group of workers will on average not contribute to an increase in value added until the future, in other words after completion of the apprenticeship. With regard to the technical equipment, it is found that organisations with older, less up-to-date equipment also exhibit lower organisational performance.

Starting with demographic faultlines (Model 1), the fixed-effects model reveals a significantly negative effect, which is in line with the theoretical expectations. The more distinct the faultlines is, the lower the level of performance in the organisation is, too: an increase in the demographic faultline by 1 percentage point leads to an increase in productivity of about 0.1 percent. Introducing interaction effects (Model 2), we can see that there are positive interaction effects for all organisation size categories except for the largest one. More precisely, whereas for organisations with less than 5 members the effect of demographic faultlines is negative with 0.16 percentage decrease in productivity, for organisations with 5 to 10 members the effect is reduced to $-0.03(-0.00164+0.00132)$. Already for organisations with more than 10 members, the effect becomes positive and increases by organisation size until it turns negative again for the largest organisations with an overall effect of about -0.15 percent. 
Table 4: Effects of faultlines on organisational productivity

\begin{tabular}{|c|c|c|c|c|}
\hline Variables & $\begin{array}{l}\text { Model } 1 \\
\text { Demographic } \\
\text { Faultline } \\
\end{array}$ & $\begin{array}{l}\text { Model } 2 \\
\text { Demographic } \\
\text { Faultline } \\
\end{array}$ & $\begin{array}{l}\text { Model } 3 \\
\text { Functional } \\
\text { Faultline } \\
\end{array}$ & $\begin{array}{l}\text { Model } 4 \\
\text { Functional } \\
\text { Faultline } \\
\end{array}$ \\
\hline \multirow[t]{2}{*}{ Faultline measure } & $-0.00099 * * *$ & $-0.00164 * * *$ & -0.00011 & -0.00023 \\
\hline & $(0.000)$ & $(0.000)$ & $(0.000)$ & $(0.000)$ \\
\hline \multirow[t]{2}{*}{ 5-9 members } & $-0.25851 * * *$ & $-0.29334 * * *$ & $-0.27544 * * *$ & $-0.28291 * * *$ \\
\hline & $(0.016)$ & $(0.024)$ & $(0.016)$ & $(0.020)$ \\
\hline \multirow[t]{2}{*}{ 10-19 members } & $-0.42840 * * *$ & $-0.49473 * * *$ & $-0.44926 * * *$ & $-0.46197 * * *$ \\
\hline & $(0.022)$ & $(0.036)$ & $(0.023)$ & $(0.031)$ \\
\hline \multirow[t]{2}{*}{ 20-49 members } & $-0.58103 * * *$ & $-0.66434 * * *$ & $-0.60211^{* * *}$ & $-0.60902 * * *$ \\
\hline & $(0.029)$ & $(0.050)$ & $(0.029)$ & $(0.043)$ \\
\hline \multirow[t]{2}{*}{ 50-99 members } & $-0.74776^{* * *}$ & $-0.89391 * * *$ & $-0.77185 * * *$ & $-0.78444 * * *$ \\
\hline & $(0.035)$ & $(0.065)$ & $(0.035)$ & $(0.049)$ \\
\hline \multirow[t]{2}{*}{ 100-199 members } & $-0.90686 * * *$ & $-1.06894 * * *$ & $-0.93326^{* * *}$ & $-0.96551 * * *$ \\
\hline & $(0.045)$ & $(0.080)$ & $(0.045)$ & $(0.076)$ \\
\hline \multirow[t]{2}{*}{200 and more members } & $-1.06705^{* * *}$ & $-1.07313 * * *$ & $-1.09749 * * *$ & $-1.12622 * * *$ \\
\hline & $(0.060)$ & $(0.105)$ & $(0.060)$ & $(0.105)$ \\
\hline \multirow[t]{2}{*}{ 5-9 members*faultline } & & $0.00132 *$ & & 0.00024 \\
\hline & & $(0.001)$ & & $(0.000)$ \\
\hline \multirow[t]{2}{*}{ 10-19 members*faultline } & & $0.00235^{* *}$ & & 0.00040 \\
\hline & & $(0.001)$ & & $(0.001)$ \\
\hline \multirow[t]{2}{*}{ 20-49 members*faultline } & & $0.00292 *$ & & 0.00021 \\
\hline & & $(0.001)$ & & $(0.001)$ \\
\hline \multirow[t]{2}{*}{ 50-99 members*faultline } & & $0.00503 * *$ & & 0.00039 \\
\hline & & $(0.002)$ & & $(0.001)$ \\
\hline \multirow[t]{2}{*}{ 100-199 members*faultline } & & $0.00553 *$ & & 0.00102 \\
\hline & & $(0.002)$ & & $(0.002)$ \\
\hline \multirow[t]{2}{*}{200 and more members*faultline } & & 0.00009 & & 0.00089 \\
\hline & & $(0.003)$ & & $(0.003)$ \\
\hline
\end{tabular}

Notes: Fixed effects regressions; additional control variables: establishment size, share of skilled workers, share of fixedterm contracts, share of part-time employees, share of apprentices and the organisations' technical equipment; robust standard errors in parentheses; $* * *, * * *$ denotes significance at the $0.1,1$, or 5 percent level, respectively.

In all, the results support hypothesis $2 \mathrm{a}$ and to a large degree hypothesis $2 \mathrm{~b}$ for demographic faultlines, where the latter is an inversely u-shaped relationship instead of the hypothesised steady decrease. Regarding functional faultlines (Model 3 and 4 in Table 4) we observe a positive faultline effect which turns negative in case of the interacted model. Since both coefficients as well as all interaction terms are clearly insignificant the findings of these models do not provide support for our hypotheses $2 \mathrm{a}$ and $2 \mathrm{~b}$ in the case of functional faultlines. 


\section{Summary and discussion}

This study examines the effects of an increasing multidimensional diversity on turnover and performance of organisations. To this end we use the faultline approach, which says that a polarised demographic composition can result in the formation of dividing lines that split a group into two or more different subgroups. This polarisation makes cooperation in organisations more difficult and encourages the emergence of conflicts. From a theoretical viewpoint, it should hamper organisational performance and foster turnover.

We distinguish between functional and demographic faultlines as independent and turnover and performance as dependent variables. The data allows us not only to obtain representative results for Germany but also to distinguish effects for different organisation sizes. Our results for turnover largely contradict results obtained from research on work groups. Where the later often finds positive effects on turnover, we find also positive but insignificant effects for demographic faultlines. For functional diversity we only find effects in very large organisations. One explanation for this contradiction is that leaving a work group embedded within a larger organisation is in general not as costly as leaving an organisation of the same size. In the former case leaving might only mean changing from one department to another, where in the latter case it means changing jobs which comes along with various costs. Furthermore, because many work group studies were conducted in the laboratory, our results might cast doubt on the external validity of such studies. This does not mean that faultlines in organisations as compared to work groups do not lead to conflicts, but only that if they do, they are not typically resolved by leaving the organisation.

The data reveal a different picture for the relationship between faultlines and performance, however. First, there are no effects of functional faultlines on organisational performance. Second, whereas at first it seems that faultlines have the same negative impact in 
organisations as in work groups, interactions with organisation size showed a more nuanced pattern. Smaller organisations that are more similar to work groups in terms of size show the same negative effects of demographic faultlines. In organisations larger than 10 members, the effect of demographic faultlines on performance becomes positive. The reason for this could be that in smaller units, faultline-induced conflict hampers diversityinduced performance effects, as indicated in our results above. In larger units, however, where individual workers can avoid dissimilar others, conflicts can be avoided and therefore positive effects on performance seem to prevail.

Taken together the results might be interpreted as follows. Contrary to work groups, leaving an organisation is more costly. Therefore, conflict arising from faultlines within an organisation does in general not lead to higher turnover. With the exception of functional diversity this holds irrespective of organisation size. In small organisations, exiting the work group is identical to leaving the organisation. As our results indicate, leaving the organisations seems to be avoided, even in the presence of faultline and - presumably - the conflicts between polarised sub-groups within the organisation. In contrast, the larger the organisation, the less likely the faultlines run through workgroups. Furthermore, if they do, changing for example from one team or department to another provides a less costly way of conflict resolution. Therefore, effects of demographic faultlines can become positive for organisations with larger than 10 members.

Our data has several advantages over those typically used in faultline research. They are representative for Germany, allow to differentiate between organisations of different sizes and offer objective measures for turnover as well as performance. At the same time, relying on large-scale objective data does not allow us to identify whether faultlines indeed leads to conflicts within the organisation, but only conjecture this effect from our results on organisational performance and turnover. However, a data set that is representative with 
regard to organisations and contains exact information on demographic composition of the whole organisation that also includes information on individual members perceived conflicts with others does not exist to the best of our knowledge. Until such data is available, we consider our results to be an important step forward for understanding the effects of faultlines in organisations. 


\section{References}

Alexander J, Nuchols B, Bloom J and Lee SY (1995) Organizational Demography and Turnover: An Examination of Multiform and Nonlinear Heterogeneity. Human Relations 48: $1455-1480$.

Ali M, Metz I and Kulik C (2010) The impact of gender diversity on turnover: the moderating effect of human resource policies and practices. Academy of Management Annual Meeting Proceedings, Academy of Management, Montreal.

Andersson F, García-Pérez M, Haltiwanger J, McCue K and Sanders S (2014) Workplace Concentration of Immigrants. Demography 51:2281-2306.

Backes-Gellner U and Veen S (2013) Positive effects of ageing and age diversity in innovative companies - large-scale empirical evidence on company productivity. Human Resource Management Journal 23(3): 279-295.

Blau PM (1977) Inequality and Heterogeneity: A Primitive Theory of Social Structure. New York: Free Press.

Blau FD and Kahn LM (2013) Female Labor Supply: Why Is the United States Failing Behind? The American Economic Review 103 (3):251-256.

Bezrukova K, Jehn K, Zanutto E and Thatcher SMB (2009) Do workgroup faultlines help or hurt? A moderated model of faultlines, team identification, and group performance. Organization Science 20 (1): 35-50.

Buche A, Jungbauer-Gans M, Niebuhr A and Peters C (2013) Diversität und Erfolg von Organisationen. Zeitschrift für Soziologie 42(6): 483-501. 
Boerner S, Keding H and Hüttermann H (2012) Gender Diversity und Organisationserfolg - Eine kritische Bestandsaufnahme. Schmalenbachs Zeitschrift für betriebswirtschaftliche Forschung 64: 37-70.

Burgess S, Lane J and Stevens D (1999) Job flows, worker flows and churning. Journal of Labor Economics 18: 473-502.

Cipollone, A and D'Ippoliti C (2011) Women's employment: joining explanations based on individual characteristics and on contextual factors. American Journal of Economics and Sociology 70(3): 756-783.

Choi JN and Sy T (2010) Group-level organizational citizenship behaviour: Effects of demographic faultlines and conflict in small work groups. Journal of Organizational Behavior 31(7): 1032-1054

Cohen P (2013) The Persistence of Workplace Gender Segregation. Sociology Compass 7(11): 889-99.

Dawson JF (2012) Measurement of work group diversity. Doctoral Thesis, Aston University.

DiTomaso N, Post C und Parks-Yancy R (2007) Workforce Diversity and Inequality: Power, Status, and Numbers. Annual Review of Sociology 33: 473-501.

Egan TM, Yang B and Bartlett KR (2004) The effects of organizational learning culture and job satisfaction on motivation to transfer learning and turnover intention. Human Resource Development Quarterly 15(3): 279-301.

Esteban J and Ray D (1994) On the Measurement of Polarization. Econometrica 62 (4): $819-852$. 
Fernández R (2013) Cultural Change as Learning: The Evolution of Female Labor Force Participation over a Century. The American Economic Review 103 (1): 472-500.

Guillaume YR, Dawson JF, Otaye-Ebede L, Woods SA and West MA (2015) Harnessing demographic differences in organizations: What moderates the effects of workplace diversity? Journal of Organizational Behaviour (Version of Record online: 22 JUL 2015)

Habyarimana J, Humphreys M, Posner DN and Weinstein JM (2007) Why Does Ethnic Diversity Undermine Public Goods Provision? American Political Science Review 101: 709-725.

Harrison DA and Klein CJ (2007) What's the Difference? Diversity Constructs as Separation, Variety or Disparity in Organizations. Academy of Management Review 32(4): $1199-1228$.

Herring C (2009) Does Diversity Pay?: Race, Gender, and the Business Case for Diversity. American Sociological Review 74: 208-224.

Ilmakunnas P and Ilmakunnas S (2011) Diversity at the Workplace: Whom Does it Benefit? De Economist 159(2): 223-255.

Van Knippenberg D and Schippers MC (2007) Work Group Diversity. Annual Review of Psychology 58: 515-41.

Kunze F, Boehm SA and Bruch H (2010) Age diversity, age discrimination climate and performance consequences - a cross organizational study. Journal of Organizational Behavior 32: 264-290. 
Lambert EG, Hogan NL and Barton SM (2001) The impact of job satisfaction on turnover intent: a test of a structural measurement model using a national sample of workers. The Social Science Journal 38(2): 233-250.

Lau DC and Murnighan JK (1998) Demographic Diversity and Faultlines: The Compositional Dynamics of Organizational Groups. The Academy of Management Review 23 (2): 325-340.

Lau D and Murnighan JK (2005) Interactions within groups and subgroups: The effects of demographic faultlines. Academy of Management Journal 48: 645-659.

Leonesio MV, Bridges B, Gesumaria R and Del Bene L (2012) The Increasing Labor Force Participation of Older Workers and its Effect on the Income of the Aged. Social Security Bulletin 72(1): 59-77.

Li J and Hambrick DC (2005) Factional groups: A new vantage on demographic faultlines, conflict, and disintegration in work teams. Academy of Management Journal 48: 794-813.

Li J, Chu CWL, Lam KCK and Liao S (2011) Age diversity and firm performance in an emerging economy: Implications for cross-cultural human resource management. Human Resource Management 50(2): 247-270.

Meyer B, Glenz A (2017): Calculating diversity faultlines with the asw.cluster package in R: A step-by-step guide for beginners. Available at http://www.group-faultlines.org, last accessed August 10, 2017

Milliken FJ and Martins LL (1996) Searching for Common Threads: Understanding the Multiple Effects of Diversity in Organizational Groups. The Academy of Management Review 21 (2): 402-433. 
Pfeffer J and O'Reilly CA (1987) Hospital demography and turnover among nurses. Hospital demography and turnover among nurses. Industrial Relations 26: 158-173.

Richard OC (2000) Racial Diversity, Business Strategy, and Firm Performance: A Resource-Based View. Academy of Management Journal 43: 164-177.

Robinson G and Dechant K (1997) Building a Business Case for Diversity. The Academy of Management Executive 11(3): 21-31.

Thatcher S, Jehn KA and Zanutto E (2003) Cracks in diversity research: The effects of diversity faultlines on conflict and performance. Group Decision and Negotiation 12: $217-$ 241.

Thatcher SMB and Patel PC (2011) Group Faultlines: A Review, Integration, and Guide to Future Research. Journal of Management 38: 969-1009.

Trax M, Brunow S and Suedekum J (2012) Cultural Diversity and Plant-Level Productivity. Regional Science and Urban Economics 53: 85-96.

Trezzini B (2013) A measure of multidimensional polarization for categorical diversity data. Quality and Quantity 47: 313-333.

Varian HR (1992) Microeconomic Analysis. New York: Norton \& Company.

Williams KY and O`Reilly, CA (1998) Demography and diversity in organizations: A review of 40 years of research. Research in Organizational Behavior 20: 77-140.

Zatzick CD, Elvira MM and Cohen MLE (2003) When Is More Better? The Effects of Racial Composition on Voluntary Turnover. Organization Science 14(5): 483-496. 


\section{Appendix}

\section{Table A1: Fixed effects regression, full results (only interacted models)}

\begin{tabular}{|c|c|c|c|c|}
\hline & $\begin{array}{l}\text { Turnover } \\
\text { demographic } \\
\text { faultline }\end{array}$ & $\begin{array}{l}\text { Productivity } \\
\text { demographic } \\
\text { faultline }\end{array}$ & $\begin{array}{l}\text { Turnover } \\
\text { functional } \\
\text { faultline }\end{array}$ & $\begin{array}{l}\text { Productivity } \\
\text { functional } \\
\text { faultline }\end{array}$ \\
\hline \multirow[t]{2}{*}{ Faultline measure } & 0.00011 & $-0.00164 * * *$ & 0.00006 & -0.00023 \\
\hline & $(0.000)$ & $(0.000)$ & $(0.000)$ & $(0.000)$ \\
\hline \multirow[t]{2}{*}{ 5-9 members } & 0.00152 & $-0.29334 * * *$ & -0.00291 & $-0.28291 * * *$ \\
\hline & $(0.005)$ & $(0.024)$ & $(0.005)$ & $(0.020)$ \\
\hline \multirow[t]{2}{*}{ 10-19 members } & -0.00228 & $-0.49473 * * *$ & 0.00854 & $-0.46197 * * *$ \\
\hline & $(0.009)$ & $(0.036)$ & $(0.008)$ & $(0.031)$ \\
\hline \multirow[t]{2}{*}{ 20-49 members } & 0.00563 & $-0.66434 * * *$ & 0.00062 & $-0.60902 * * *$ \\
\hline & $(0.013)$ & $(0.050)$ & $(0.013)$ & $(0.043)$ \\
\hline \multirow[t]{2}{*}{ 50-99 members } & 0.00750 & $-0.89391 * * *$ & 0.02818 & $-0.78444 * * *$ \\
\hline & $(0.017)$ & $(0.065)$ & $(0.019)$ & $(0.049)$ \\
\hline \multirow[t]{2}{*}{ 100-199 members } & 0.01977 & $-1.06894 * * *$ & 0.03940 & $-0.96551 * * *$ \\
\hline & $(0.018)$ & $(0.080)$ & $(0.031)$ & $(0.076)$ \\
\hline \multirow[t]{2}{*}{200 and more members } & $0.04688^{*}$ & $-1.07313^{* * *}$ & 0.02993 & $-1.12622 * * *$ \\
\hline & $(0.023)$ & $(0.105)$ & $(0.022)$ & $(0.105)$ \\
\hline \multirow[t]{2}{*}{ 5-9 members*faultline measure } & -0.00003 & $0.00132 *$ & 0.00014 & 0.00024 \\
\hline & $(0.000)$ & $(0.001)$ & $(0.000)$ & $(0.000)$ \\
\hline \multirow[t]{2}{*}{ 10-19 members*faultline measure } & 0.00028 & $0.00235^{* *}$ & -0.00005 & 0.00040 \\
\hline & $(0.000)$ & $(0.001)$ & $(0.000)$ & $(0.001)$ \\
\hline \multirow[t]{2}{*}{ 20-49 members*faultline measure } & 0.00010 & $0.00292^{*}$ & 0.00030 & 0.00021 \\
\hline & $(0.000)$ & $(0.001)$ & $(0.000)$ & $(0.001)$ \\
\hline \multirow[t]{2}{*}{ 50-99 members*faultline measure } & 0.00059 & $0.00503 * *$ & -0.00006 & 0.00039 \\
\hline & $(0.001)$ & $(0.002)$ & $(0.000)$ & $(0.001)$ \\
\hline \multirow[t]{2}{*}{ 100-199 members*faultline measure } & 0.00079 & $0.00553^{*}$ & 0.00016 & 0.00102 \\
\hline & $(0.001)$ & $(0.002)$ & $(0.001)$ & $(0.002)$ \\
\hline \multirow[t]{2}{*}{200 and more members $*$ faultline measure } & 0.00063 & 0.00009 & $0.00120^{*}$ & 0.00089 \\
\hline & $(0.001)$ & $(0.003)$ & $(0.000)$ & $(0.003)$ \\
\hline \multirow[t]{2}{*}{ Skilled workers (share) } & $-0.01322 * *$ & $0.04123^{* * *}$ & $-0.01314 * *$ & $0.04511^{* * *}$ \\
\hline & $(0.004)$ & $(0.012)$ & $(0.004)$ & $(0.012)$ \\
\hline \multirow[t]{2}{*}{ Part-time workers (share) } & $0.02300 * * *$ & $-0.20582 * * *$ & & \\
\hline & $(0.006)$ & $(0.017)$ & & \\
\hline \multirow[t]{2}{*}{ Fixed-term workers (share) } & $0.11338 * * *$ & $-0.08095^{* *}$ & $0.11374 * * *$ & $-0.09131 * *$ \\
\hline & $(0.013)$ & $(0.030)$ & $(0.013)$ & $(0.030)$ \\
\hline \multirow[t]{2}{*}{ Apprentices (share) } & $-0.07203 * * *$ & $-0.26106^{* * *}$ & $-0.07525 * * *$ & $-0.23060 * * *$ \\
\hline & $(0.011)$ & $(0.043)$ & $(0.011)$ & $(0.043)$ \\
\hline \multirow[t]{2}{*}{ Technical equipment } & -0.00015 & $-0.00833 * *$ & -0.00020 & $-0.00867 * *$ \\
\hline & $(0.001)$ & $(0.003)$ & $(0.001)$ & $(0.003)$ \\
\hline Observations & 117,949 & 67,746 & 117,949 & 67,746 \\
\hline R-squared & 0.012 & 0.069 & 0.012 & 0.068 \\
\hline
\end{tabular}

$\beta$-coefficients are shown. $* * *, * *, *$ denotes significance at the $0.1,1$, or 5 percent level respectively. Year dummies and a dummy indicating type of sales (only turnover models) are included. Source: IAB Establishment Panel 20002009/LIAB (QM 2 9308). 
Table A2: Fixed effects regression, models including both faultline measures

\begin{tabular}{|c|c|c|c|c|}
\hline & Productivity (I) & Productivity (II) & Turnover (I) & Turnover (II) \\
\hline \multirow[t]{2}{*}{ Demographic faultline } & $-0.00187 * * *$ & $-0.00189 * * *$ & 0.00010 & 0.00011 \\
\hline & $(0.000)$ & $(0.000)$ & $(0.000)$ & $(0.000)$ \\
\hline \multirow[t]{2}{*}{ 5-9 members* demogr. faultline } & $0.00148 * *$ & $0.00148 * *$ & -0.00007 & -0.00007 \\
\hline & $(0.001)$ & $(0.001)$ & $(0.000)$ & $(0.000)$ \\
\hline \multirow[t]{2}{*}{ 10-19 members* demogr. faultline } & $0.00252 * *$ & $0.00261 * *$ & 0.00030 & 0.00029 \\
\hline & $(0.001)$ & $(0.001)$ & $(0.000)$ & $(0.000)$ \\
\hline \multirow[t]{2}{*}{ 20-49 members* demogr. faultline } & $0.00320^{*}$ & $0.00332 * *$ & 0.00000 & 0.00001 \\
\hline & $(0.001)$ & $(0.001)$ & $(0.000)$ & $(0.000)$ \\
\hline \multirow[t]{2}{*}{ 50-99 members* demogr. faultline } & $0.00535^{* *}$ & $0.00538 * *$ & 0.00062 & 0.00058 \\
\hline & $(0.002)$ & $(0.002)$ & $(0.001)$ & $(0.001)$ \\
\hline \multirow[t]{2}{*}{ 100-199 members* demogr. faultline } & $0.00579^{*}$ & $0.00585^{*}$ & 0.00075 & 0.00051 \\
\hline & $(0.002)$ & $(0.002)$ & $(0.001)$ & $(0.001)$ \\
\hline \multirow[t]{2}{*}{200 and more members* demogr. faultline } & -0.00009 & -0.00028 & 0.00022 & 0.00027 \\
\hline & $(0.003)$ & $(0.003)$ & $(0.001)$ & $(0.001)$ \\
\hline \multirow[t]{2}{*}{ Functional faultline } & 0.00045 & 0.00032 & 0.00002 & 0.00003 \\
\hline & $(0.000)$ & $(0.000)$ & $(0.000)$ & $(0.000)$ \\
\hline \multirow[t]{2}{*}{ 5-9 members* funct. faultline } & -0.00019 & -0.00024 & 0.00019 & 0.00017 \\
\hline & $(0.000)$ & $(0.000)$ & $(0.000)$ & $(0.000)$ \\
\hline \multirow[t]{2}{*}{ 10-19 members* funct. faultline } & -0.00024 & -0.00025 & -0.00006 & -0.00008 \\
\hline & $(0.001)$ & $(0.001)$ & $(0.000)$ & $(0.000)$ \\
\hline \multirow[t]{2}{*}{ 20-49 members* funct. faultline } & -0.00062 & -0.00057 & 0.00034 & 0.00032 \\
\hline & $(0.001)$ & $(0.001)$ & $(0.000)$ & $(0.000)$ \\
\hline \multirow[t]{2}{*}{ 50-99 members* funct. faultline e } & -0.00078 & -0.00065 & -0.00017 & -0.00013 \\
\hline & $(0.001)$ & $(0.001)$ & $(0.001)$ & $(0.001)$ \\
\hline \multirow[t]{2}{*}{ 100-199 members* funct. faultline } & -0.00050 & -0.00032 & -0.00001 & 0.00007 \\
\hline & $(0.002)$ & $(0.002)$ & $(0.001)$ & $(0.001)$ \\
\hline \multirow[t]{2}{*}{200 and more members* funct. faultline } & 0.00090 & 0.00087 & $0.00113^{*}$ & $0.00116^{*}$ \\
\hline & $(0.003)$ & $(0.003)$ & $(0.001)$ & $(0.001)$ \\
\hline
\end{tabular}

$\beta$-coefficients are shown. $* * *, * *, *$ denotes significance at the $0.1,1$, or 5 percent level respectively. Other controls as in Table A1 also included. Models marked with (II) are without part-time workers as control variable. Source: IAB Establishment Panel 2000-2009/LIAB (QM 2 9308). 